\title{
Persepsi Masyarakat Pekanbaru Tentang Perbankan Syariah Dan Penyebab Masyarakat Tidak Memilih Bank Syariah
}

\author{
RENI FARWITAWATI \\ Universitas Lancang Kuning \\ Jln. Yos Sudarso KM 08 Rumbai Telp. (0761) 52581 \\ E-mail : reni@unilak.ac.id
}

\begin{abstract}
In Pekanbaru itself is few people having an account at the bank syariah. The pekanbaru predominantly sunni muslim with this should be able to give a big chance of progress syariah banks in pekanbaru. In many studies that motivation is because someone chosen syariah bank syariah banks use system islam with the syariah principle. When research explaining that the main factor of the community chose syariah banks religion, why in riau especially in pekanbaru that the ownership of the predominantly muslim syariah bank accounts at very low. If religion in research mentioned are the main cause a person chooses syariah banks did not apply for the pekanbaru. The research is the qualitative study which aims to answer the question of how perceptions of about syariah banking and the cause of the community did not choose syariah banks. Data were collected from interview directly with the people residing in pekanbaru. Interviews were conducted to community members who do not choose bank syariah as an institution financial. Next, research this analyzed use descriptive qualitative. The results of the study shows that the people who did not vote their status into syariah banks thinking it is cute to their status into syariah banks equal to that of conventional banks. The payment is stalled because the level of the knowledge of a community that are low in the remembrance of the lack of promotion is held by bank of a new shariah bank. The community is still feel that the information passed on to them about customers including syariah banking products began to get a bit of a system of, the concept of until their products very few. A factor causing the community did not their status into syariah banks on monday to elect the namely in knowledge about a tub of a new shariah bank, the product until attract the that was very low to, the payment is stalled because of a promotion that was carried out by their status into syariah banks less able to touch the community in fact were still a little the information they receive from this promotion. Besides the existence of service station in syariah banks and the bank atm facilities very few a result of being around the community. Furthermore there are also various branding their status into syariah banks what is felt to be less interesting customer to enable them to, that this is true because the opening major of the as well as promos that held by bank of a new shariah bank being scanty. See the state of a community which is like it, their status into syariah banks wanted to regain title to you his revelations education to the people conveying of the bank to retail and corporate banking, began to get a bit of a system of until product. Their status into syariah banks is expected to deliver education on the of a promotion that by drawing close to the people directly. In addition the fulfilment of rudimentary facility living that support the customer to enable them to act to provide service for is also needed in order to provide the best services to the community
\end{abstract}

Keywords: Perception, Syariah Banking, Syariah Banks

Bank syariah mulai berkembang pada era 90an dengan diawali oleh bank Muamalat pada saat itu telah memberikan warna baru bagi perbankan di Indonesia. Indonesia tergolong lambat mengingat terdapat beberapa negara lain yang telah mengadopsi bank syariah menjadi bagian dari perbankan di negaranya. Keterlambatan itu bukan lah menjadi penghalang dari tumbuh kembang perbankan syariah di Indonesia umumnya dan di Pekanbaru khususnya.

Nada sinisme masih sering terdengar sebagian besar umat Islam terhadap perbankan syariah dan lembaga keuangan syariah lainnya, misalnya perbedaan bank syariah dengan bank konvensional hanya kosa kata belaka 
yaitu "bunga " diganti dengan "bagi hasil". Umumnya orang hanya tahu bahwa bank syariah adalah bank tanpa bunga dan tidak tahu sama sekali mengenai mekanisme "bagi hasil" sehingga sering bertanya-tanya kalau menabung di bank syariah dan tidak mendapatkan bunga lalu saya mendapat apa. Disisi lain menurut persepsi mereka yang namanya bagi hasil pasti nilainya lebih kecil dari bunga bank.

Sementara bank syariah dengan sistem bagi hasil tidak memberikan kepastian pendapatan sebagaimana bunga bank konvensional memberikan kepastian pendapatan. Sedang menurut sebagian pedagang yang membutuhkan pinjaman, menyatakan kredit di bank syariah prosesnya rumit dan berbelit-belit. Bank syariah juga masih dipandang sebagai lembaga sosial seperti menyalurkan zakat dan memberikan uang tanpa perlu mengembalikan.

Ada pula yang berpendapat suku bunga di bank konvensinal bukan riba selama tidak melebihi tingkat inflasi sekitar $10 \%$ seperti sekarang ini, sehingga suku bunga bank $10 \%$ atau kurang dari $10 \%$ berarti bukan riba. Bunga itu hanya penggantian terhadap nilai uang yang turun dari akibat inflasi tadi. Argumentasi ini menjadi alasan mengapa lebih memilih bank konvensional.

Suara sumbangpun masih sering terdengar dari sebagian umat Islam dengan menyebut bank syariah hanya mengeksploitir rasa sentimen keagamaan saja. Tak dipungkiri diterapkannya konsep bank syariah di Indonesia mengundang nada sinis dikalangan umat Islam sendiri. Sebagai pendatang baru di blantika perbankan, konsep bank syariah menghadapi situasi sulit, umat Islam yang awam dengan budaya perbankan dan masyarakat yang hidup dalam cengkeraman ekonomi kapitalis sejak ratusan abad.

Kesalahpahaman terhadap perbankan syariah dan lembaga keuangan syariah lainnya menunjukkan belum meratanya sosialisasi informasi perbankan syariah dan lembaga Keuangan Syariah lainnya. Banyak masyarakat yang belum memahami secara benar apa itu lembaga Keuangan syariah, system yang dipakai, jenis produknya, serta apa keunggulan lembaga keuangan syariah bila dibandingkan dengan lembaga keuangan konvensional.

Fakta lain yang ikut membentuk persepsi masyarakat terhadap Lembaga Keuangan Syariah, yaitu komunikasi atau promosi yang dilakukan lembaga keuangan syariah kurang maksimal. Padahal promosi sangat efektif untuk sosialisasi, membentuk image dan merubah perilaku masyarakat menuju system keuangan syariah. Banyak faktor penyebab Lembaga Keuangan Syariah kurang berpromosi dalam rangka meningkatkan penjualan diantaranya anggaran promosi yang relative masih kecil, bila dibandingkan dengan lembaga keuangan konvensional. Disamping keterbatasan lain seperti SDM Lembaga Keuangan syariah.

Hal ini menjadi tantangan
Perbankan syariah dan Keuangan syariah lainnya, namun juga ujian bagi umat Islam secara keseluruhan mulai dari Majelis Ulama Indonesia (MUI), ormas-ormas Islam, Parpol Islam, para akademisi, cendekiawan muslim serta seluruh komponen umat Islam yang mempunyai komitmen terhadap perkembangan ekonomi syariah untuk mensosialisasikan secara merata agar masyarakat sadar dan memahami secara benar terhadap Perbankan Syariah dan Lembaga Keuangan Syariah lainnya. Ini merupakan kerja besar yang memerlukan waktu, kebersamaan dan sinergi, usaha serius serta dana yang tidak sedikit.

Keberhasilan sistem keuangan syariah hingga sekarang ini tidak sematamata atas adanya dukungan regulasi pemerintah, namun juga didukung oleh kualitas dan pelayanan yang diberikan oleh lembaga tersebut. Lembaga keuangan syariah yang dalam hal ini adalah perbankan syariah secara umum, 
dianggap oleh sebagian orang sebagai alternative bagi masyarakat yang sudah jenuh dengan system ekonomi kapitalis, sebuah system ekonomi yang sudah lama mendunia yang selalu mengutamakan kekayaan pribadi berdampak pada ketidakmerataan distribusi kekayaan sehingga banyak terjadi kesengsaraan.

Namun sisi lain, tidak sedikit masyarakat yang masih menganggap bahwa system ekonomi syariah hanya hadir untuk masyarakat muslim. Tidak bisa dipungkiri, paradigma fanastisme agama masih kental terlihat dalam masyarakat kita, persepsi masyarakat yang berkembang bahwa bank syariah sebagai bank untuk kaum muslim saja, pasar yang tertutup untuk kalangan non muslim. Padahal, system bagi hasil yang merupakan salah satu elemen penting dari pasar syariah dan sudah sejak lama diterapkan Negara-negara Eropa, terutama Inggris. Jadi, persepsi bahwa pasar konvensional selalu lebih menguntungkan dan pasar syariah adalah pasarnya kaum mulim tidak tepat. Kemudian bagaimana dengan citra Islam dan apakah yang ditawarkan untuk menarik para nasabah, sedangkan citra Islam belum menjadi daya tarik nomor satu bahkan dikalangan umat Islam sendiri.

Melihat fenomena tersebut, masyarakat mulai sadar bahwa bank-bank konvensional yang ada saat ini tidak bisa menjadi solusi terbaik dari problemproblem yang ada didalam masyarakat, sehingga masyarakat melirik kembali ajaran Islam yang bebas riba. Perbankan syariah merupakan suatu badan usaha yang fungsinya sebagai penghimpun dana dari masyarakat dan penyalur dana kepada masyarakat, yang system dan mekanisme kegiatan usahanya berdasarkan hukum Islam.

Masyarakat muslim yang menggunakan jasa perbankan syariah menganggap bahwa bunga adalah riba. Hal ini secara tergas dinyatakan dalam $\mathrm{Al}$ Quran yaitu dalam surat al-Baqarah ayat 278-279. Pelarangan riba ternyata tidak hanya terdapat dalam Islam, melainkan jauh sebelum Islam ada. Di India Kuno, hukum yang berdasarkan Weda, kitab suci tertua agama Hindu, mengutuk riba sebagai sebuah dosa besar dan melarang operasi bunga. Riba merupakan suatu tambahan lebih dari modal asal, biasanya transaksi riba sering dijumpai dalam transaksi hutang piutang dimana kreditor sering dijumpai dalam transaksi hutang piutang dimana kreditor meminta tambahan dari modal asal kepada debitur (Chair, 2014).

Di Pekanbaru sendiri masih sedikit sekali orang yang memiliki rekening di bank syariah. Penduduk Pekanbaru mayoritas beragama Islam dengan ini seharusnya dapat memberikan peluang besar terhadap kemajuan bank syariah di Pekanbaru. Dalam banyak studi bahwa motivasi seseorang memilih bank syariah adalah karena bank syariah menggunakan system-sistem dengan prinsip syariah Islam. Seperti dalam penelitian Metawa dan Almosawi dalam penelitian Mita Widyastuti. Ada tiga criteria tertinggi yang dipertimbangkan calon nasabah di bank syariah. Pertama prinsip nasabah yang sesuai dengan keyakinan calon nasabah, kedua adalah saran atau rekomendasi mengenai bank yang bersangkutan, ketiga adalah kenyamanan dari lokasi bank. Menurut Karim Business Counsulting (KBC) dalam penelitian Mita Widyastuti, motivasi memilih bank syariah ialah menggunakan prinsip yang sesuai dengan prinsip Islam dengan kata lain agama atau religius menjadi alasan masyarakat memilih bank syariah. Seperti yang terdapat dalam penelitian KBC, factor yang menjadi alasan memilih bank syariah adalah (1) sistemnya sesuai syariah, (2) pengelolaannya kredibel, (3) nilai bagi hasil yang tinggi, (4) lokasi bank dekat rumah, (5) pelayanannya cepat, (6) tidak dikenakan biaya administrasi, (7) tempat penerimaan gaji, (8) customer service/ tellernya ramah. Dalam penelitian ini diketahui bahwa $71 \%$ responden menjadi nasabah bank syariah karena agama. 
Alasan seseorang memilih bank syariah disebutkan dalam penelitian Hamidi dkk, dalam penelitian Mita Widyastuti (2008) yaitu (1) sesuai dengan agama yang dianut (2) jasa sesuai dengan kebutuhan (3) bonafiditas dan keamanan (4) variasi produk (5) sikap dan perilaku karyawan yang sesuai dengan syariah (6) pelayanan cepat dan lain-lain. Jika dalam studi penelitian mengatakan bahwa agama menjadi factor pendorong yang paling utama masyarakat memilih bank syariah maka seharusnya di Indonesia bank syariah berkembang sangat pesat melihat Indonesia merupakan Negara dengan penduduk muslim terbesar di dunia. Ketika agama Islam menjadi sebuah alasan masyarakat memilih bank syariah seharusnya bank syariah akan berkembang lebih cepat tidak seperti yang terjadi saat ini, bank syariah masih dalam posisi yang menjadi sebuah alternative bukan menjadi lembaga keuangan yang utama yang digunakan masyarakat Pekanbaru.

Di Pekanbaru terdapat beberapa bank syariah yang beroperasi dan mendirikan kantor pelayanan syariah diantaranya: (1) Bank Muamalat (2) Bank Syariah Mandiri (3) Bank Syariah BRI (4) Bank Syariah Bukopin (5) Bank BNI syariah (6) Bank Danamon Syariah (7) Bank BRI Syariah (8) Bank BTN Syariah (9) BPR Syariah.

Dalam kamus Indonesia persepsi adalah tanggapan (penerimaan) langsung dari sesuatu atau merupakan proses seseorang mengetahui beberapa hal yang dialami oleh setiap orang dalam memahami setiap informasi tentang lingkungan melalui panca indera. Sedangkan menurut Robbins (2009:175) mendefinisikan persepsi sebagai proses di mana individu mengatur dan menginterpretasikan kesan-kesan sensoris mereka guna memberikan arti bagi lingkungan mereka.

Menurut Ikhsan (2010:93) persepsi adalah bagaimana orang-orang melihat atau menginterpretasikan peristiwa, objek, serta manusia. Orang-orang bertindak atas dasar persepsi mereka dengan mengabaikan apakah persepsi itu mencerminkan kenyataan sebenarnya. Pada kenyataannya, setiap orang memiliki persepsinya sendiri atas suatu kejadian. Namun, apa yang diterima seseorang pada dasarnya bisa berbeda dari realitas objektif. Walaupun seharusnya tidak perlu ada, perbedaan tersebut sering timbul.

Persepsi dikatakan rumit dan aktif karena walaupun persepsi merupakan pertemuan antara proses kognitif dan kenyataan, persepsi lebih banyak melibatkan kegiatan kognitif. Persepsi lebih banyak dipengaruhi oleh kesadaran, ingatan, pikiran, dan bahasa. Dengan demikian, persepsi bukanlah cerminan yang tepat dari realitas (Ikhsan:2010;94).

Bank merupakan salah satu lembaga keuangan yang mempunyai peranan penting di dalam perekonomian suatu negara sebagai lembaga perantara keuangan Menurut Undang-Undang RI Nomor 10 Tahun 1998 tanggal 10 November 1998 tentang Perbankan, yang dimaksud dengan BANK adalah "badan usaha yang menghimpun dana dari masyarakat dalam bentuk simpanan dan menyalurkan kepada masyarakat dalam bentuk kredit dan atau bentuk-bentuk lainnya dalam rangka meningkatkan taraf hidup rakyat banyak."

Pembangunan sektor keuangan di Indonesia diharapkan mampu membawa perubahan yang positif bagi perekonomian nasional. Hal ini disebabkan karena perbankan memiliki peran yang sangat penting dalam perekonomian Indonesia. Hal ini didasarkan pada tugas pokok lembaga keuangan yang diantaranya adalah pertama, bank bertugas menyalurkan kredit kepada lembaga usaha atau perseorangan yang membutuhkan. Tujuan dari penyaluran kredit/pembiayaan adalah untuk kegiatan yang bersifat produktif. Kedua, bank memiliki tugas untuk mengumpulkan dana dengan menarik dana dari masyarakat. Ketiga, bank 
menyalurkan jasa di bidang lalu lintas dan pembayaran uang (Sofyan, 2016)

Dari pengertian diatas dapat dijelaskan secara lebih luas lagi bahwa bank merupakan perusahaan yang bergerak dalam bidang keuangan, artinya aktivitas perbankan selalu berkaitan dalam bidang keuangan (Kasmir, 2008)

Menurut A. Abdurrachman dalam Syamsu (2013) memberikan pengertian sebagai berikut, Bank adalah suatu jenis lembaga keuangan yang melaksanakan berbagai macam jasa, seperti memberikan pinjaman, mengedarkan mata uang, pengawasan terhadap mata uang, bertindak sebagai tempat penyimpanan benda-benda berharga, membiayai usaha perusahaan dan lain-lain.

$\begin{array}{ccc}\text { Berdasarkan } & \text { sistemnya bank } \\ \text { dibedakan menjadi } & \text { dua, yaitu bank } \\ \text { konvensional dan } & \text { bank syariah }\end{array}$
(Ramadhani, 2014). Bank Konvensional dan Bank Syariah Pada umumnya bank yang berkembang di Indonesia dewasa ini adalah bank yang berorientasi pada prinsip konvensional. Bank konvensional mencari keuntungan dan menentukan harga kepada para nasabahnya menggunakan dua metode yaitu: (a) Menetapkan bunga sebagai harga atau balas jasa untuk simpanan (tabungan, giro, dan deposito) dan untuk pinjaman (kredit), (b) Membebankan berbagai biayabiaya dalam nominal atau persentase terhadap berbagai jasa-jasa perbankan.

Bank syariah adalah bank yang beroperasi sesuai dengan prinsip-prinsip syariat Islam, khususnya yang menyangkut tata cara bermuamalah secara Islam. Dalam tata cara bermuamalat itu dijauhi praktikpraktik yang dikhawatirkan mengandung unsur-unsur riba dan diisi dengan kegiatankegiatan investasi atas dasar bagi hasil dan pembiayaan perdagangan atau praktikpraktik usaha yang tidak bertentangan dengan syariat Islam. Seperti halnya perbankan konvensional, perbankan syariah juga berfungsi sebagai lembaga intermediasi (intermediary institution), yaitu berfungsi menghimpun dana dari masyarakat dan menyalurkan kembali dana-dana tersebut kepada masyarakat yang membutuhkannya dalam bentuk pembiayaan (Kolistiawan, 2014).

Falsafah dasar beroperasinya bank syariah yang menjiwai seluruh hubungan transaksinya adalah efisiensi, keadilan dan kebersamaan. Efisiensi mengacu pada prinsip saling membantu secara sinergis untuk memperoleh keuntungan sebesar mungkin. Bank berdasarkan prinsip syariah melaksanakan aturan perjanjian antara bank dengan pihak lain dalam kegiatan menyimpan dana atau pembiayaan usaha berdasarkan hukum islam. Dalam menentukan harga atau mencari keuntungan, pembiayaan berdasarkan prinsip bagi hasil (mudharabah) dan prinsip penyertaan modal (musyarakah), kegiatan jual beli barang didasarkan pada prinsip memperoleh keuntungan (murabahah), dan kegiatan pemindahan kepemilikan atas barang yang disewa dari pihak bank oleh pihak lain (ijarah wa iqtina).

Bank syariah menawarkan nasabah dengan beragam produk perbankan. Produk-produk yang ditawarkan sudah tentu sangat islami, termasuk dalam memberikan pelayanan kepada nasabahnya. Produk-produk bank syariah menurut Susila (2016)mencakup Alwadi'ah (Simpanan), Pembiayaan dengan bagi hasil (Al-musyarakah, Almudharabah, Al-muza'arah, dan Almusaqah), Bai'al-Murabahah, Bai'assalam, Bai' Al-istihna', Al-Ijarah (Leasing), Al-Wakalah (Amanat), AlKafalah (Garansi), Al-Hawalah (Anjak piutang/factoring), dan Ar-Rahn (gadai),.

Menurut Nofinawati (2015) perkembangan perbankan syariah di Indonesia telah menjadi tolak ukur keberhasilan eksistensi ekonomi syariah. Bank Muamalat Indonesia sebagai bank syariah pertama dan menjadi pioneer bagi bank syariah lainnya, dan telah lebih dahulu menerapkan system ini ditengah menjamurnya bank-bank konvensional.

Bank syariah yang pertama didirikan di Indonesia adalah Bank 
Muamalat Indonesia (BMI) pada tahun 1992. Selama periode tahun 1992-1998 perkembangan bank syariah cukup lambat, hanya ada 1 unit bank syariah. Pada tahun 2005 jumlah lembaga keuangan dengan prinsip syariah telah berkembang menjadi tiga bank umum syariah, 88 bank perkreditan rakyat berbasis syariah, dan 17 unit usaha syariah. Pada tahun 2017 sudah ada 12 bank umum syariah, 22 unit usaha syariah, dan 163 bank pembiayaan rakyat syariah.

Penambahan kuantitas tersebut diimbangi oleh penetrasi jangkauan layanan. Sebelumnya pada bank maupun unit syariah hanya boleh malayani alon nasabah dikantor cabang syariah atau kantor cabang pembantu. Namun sejak office-channeling yang didasari Peraturan BI No. 8/3/PBI/2006 dan berlaku efektif Mei 2007 pelayanan jasa financing, seperti pembukuan rekening, setor, transfer, kliring dan tarik tunai bisa dilakukan dicabang bank umum yang mempunyai unit syariah (Rahmawaty, 2007)

Perkembangan perbankan syariah diperkirakan akan lebih pesat apabila didukung oleh sumberdaya manusia yang profesional dan memiliki pengalaman praktis dalam sistem perbankan islam. Faktor-faktor lain yang mempengaruhi prospek perbankan syariah antara lain kesadaran umat Islam untuk berbisnis secara syariah, ketersediaan sumberdaya manusia di bidang perbankan syariah, minat para pemilik perbankan konvensional untuk membuka divisi atau unit usaha syariah, dan payung hukum yang jelas mengatur perbankan syariah.

Praktek ekonomi Islam, keuangan syariah, maupun akuntansi syariah di Indonesia justru menjadi menarik dan tantangan tersendiri bagi para pemikir, peneliti dan tentunya para praktisi. Dikarenakan Indonesia bukan Negara dengan paham Islam sepenuhnya dan masyarakat Indonesia dengan ras, suku dan agama yang lebih beragam tentunya akan lebih menghasilkan praktek ekonomi syariah yang lebih komplit (Himawan dan Agus, 2015).

\section{METODE}

Adapun jenis dan sumber data dalam penelitian ini adalah data primer dan dan sekunder. Data primer dalam penelitian ini adalah data hasil dari wawancara terhadap subjek dalam penelitian ini yaitu masyarakat Pekanbaru. Data sekunder penelitian ini diperoleh dengan menggunakan metode tinjauan kepustakaan (library research) dan mengakses website maupun situs-situs.

Mengingat kemampuan peneliti, baik dari segi waktu maupun dana, maka peneliti menggunakan Purposive yaitu menetapkan informan/ narasumber dengan kriteria tertentu (Sugiyono, 2015:368). Kriteria responden adalah orang yang mengerti tentang perbankan syariah tetapi tidak memilih bank syariah seperti akademisi, pengusaha, pemuka masyarakat dan pemuka agama. Snowball yaitu jumlah informan diawali dari sedikit/beberapa dan akan berkembang sesuai dengan kebutuhan informasi yang digali oleh tim peneliti (Sugiyono, 2015:368).

Untuk memperoleh data yang yang dipergunakan sebagai landasan dalam penelitian maka penulis melakukan pengumpulan data dari lapangan dengan menggunakan observasi, wawancara, dokumentasi dan studi kepustakaan.

Data yang telah berhasil dikumpulkan selanjutnya akan dianalisis secara deskriptif kualitatif, yaitu analisis yang menghasilkan data deskriptif berupa kata-kata tertulis atau lisan dari orang-orang dan perilaku yang dapat diamati dengan metode yang telah ditentukan. Tujuan dari metode ini adalah untuk membuat deskripsi atau gambaran mengenai objek penelitian secara sistematis, faktual dan akurat mengenai fakta-fakta, sifat-sifat serta hubungan antar fenomena yang diselidiki.

Kemudian data tersebut diolah dan dianalisis dengan pola pikir induktif yang berarti pola pikir yang berpijak pada faktafakta yang bersifat khusus kemudian 
diteliti, dianalisis dan disimpulkan sehingga pemecahan persoalan atau solusi tersebut dapat berlaku secara umum.

\section{HASIL}

\section{Persepsi Masyarakat Terhadap Bank Syariah}

Pandangan dan persepsi masyarakat yang tidak memilih bank syariah adalah sebagai berikut: menurut Irman Majid, MA (Dosen UIN Suska Riau) bank syariah merupakan lembaga keuangan syariah yang seharusnya mampu untuk menempatkan dirinya di tengah-tengah masyarakat Indonesia umumnya dan Pekanbaru khususnya yang mayoritas muslim. Bank syariah dirasakan belum dapat meyakinkan masyarakat sebagai lembaga yang benarbenar baik untuk masyarakat dan merupakan lembaga perbankan yang menjadi sebuah pilihan utama.

Sedangkan menurut bapak Pemi Saputra seorang pengusaha, dirinya beranggapan bahwa bank syariah dan bank konvensional itu sama saja, hal inilah yang dirinya pahami selama ini. Pemberian edukasi ke masyarakat tentang perbankan syariah dirasa sangat minim sehingga masyarakat belum mengetahui tentang perbakan syariah.

Hal serupa yang diungkapkan oleh pak Anggi Angriawan (Guru) bahwa beliau merasakan bank syariah itu sama dengan bank konvensional, menggunakan konsep yang sama namun memiliki istilah yang digunakannya yang berbeda.

Menurut bapak Suhardi, S.Hi (pemuka agama) bahwa tingkat pengetahuan merupakan motivasi yang tidak kalah penting dengan agama yang dirasa masyarakat dapat mendorong untuk melakukan kegiatan keuangannya diperbankan syariah. Anggapannya bahwa pengetahuan yang rendah terhadap perbankan syariah dapat memberikan gambaran-gambaran yang berbeda yang tidak sesuai dengan bank syariah secara real. Tingkat pengetahuan ini dipengaruhi oleh edukasi yang efektif yang dilakukan bank syariah di masyarakat dengan menjelaskan tentang perbankan syariah.
Hal serupa juga dikatakan oleh Bapak Hilal (Pemuka masyarakat), dirinya juga baru mengetahui bank syariah, pengetahuannya juga sangat terbatas dengan bank syariah. Dirinya beranggapan bahwa bank syariah dan bank konvensional sama, perebedaanya mungkin hanya pada istilah-istilah yang digunakan serta produkproduknya yang diadopsi oleh masingmasing bank.

\section{Faktor Yang Menyebabkan Masyarakat Tidak Memilih Bank Syariah}

Bauran pemasaran merupakan strategi yang sangat penting terhadap kemajuan sebuah bisni. Bank syariah merupakan lembaga bisnis yang secara tidak langsung juga akan menggunakanmenggunakan strategi bauran pemasaran terhadap usaha yang dijalankannya. tempat, produk, promosi, serta harga merupakan beberapa istrumen yang berada di bauran pemasaran.

Melihat banyaknya masyarakat Pekanbaru khususnya tidak menggunakan bank syariah sebagai lembaga keuangan untuk melakukan kegiatan keuangannya, hal ini dipengaruhi oleh beberapa faktor yang salah satunya adalah faktor bauran pemasaran. Agama merupakan sesuatu yang dapat memotivasi masyarakat untuk memilih bank syariah, namun dalam realitanya di Pekanbaru yang mayoritas muslim kepemilikan bank syariah sangat minim. Maka dari itu peneliti melakukan beberapa wawancara terhadap masyarakat untuk menanyakan beberapa faktor yang mempengaruhinya untuk tidak memilih bank syariah.

Bapak Pemi Saputra mengatakan bahwa dirinya selama ini tidak memahami tentang bank syariah, mulai dari istilah yang digunakan, produk hingga tempatnya di sekitar rumahnya yang berada di Panam. Tempat memang dirasa memiliki suatu yang penting yang membuat dirinya untuk menabung di suatu bank, melihat kondisinya sebagai pengusaha yang mengharuskan untuk bekerja 24 jam, sehingga membutuhkan bank yang dekat 
dan memudahkan untuk melakukan aktifitas menabung. Selain hal tersebut pemahaman yang minim terhadap bank syariah juga dirasa membuat dirinya ragu untuk menabung di bank syariah, ragu terhadap keamana dan ragu terhadap operasionalnya.

Sedangkan Bapak Anggi Angriawan mengatakan pengetahuannya terhadap bank syariah sangat minim, bahkan dirinya mengatakan bahwa bak syariah sama dengan bank lainnya. Hal inilah yang menyebabkan dirinya tidak menabung di bank syariah, selain itu menurutnya bahwa promosi bank syariah dirasa belum menarik untuk nya tidak seperti yang dilakukan bank konvensional yang selama ini selalu mendatangi lahan usahanya untuk menawarkan produk pembiayaannya serta menawarkannya untuk produk-produk penyimpanan dana.

Bapak Hilal mengungkapkan hal bahwa tempat itu relatif jauh ataupun dekat kalau seseorang itu mengerti kebaikannya, serta secara menyeluruh tentang bank syariah maka dimanapun akan selalu di cari. Selain hal tersebut, promo yang menarik serta pendekatan diri dengan masyarakaat dengan melakukan promosi di pasar-pasara seperti yang dilakukan bank konvensional mungkin juga akan memberikan sesuatu yang lebih dari kemajuan pengetahuan masyarakat terhadap bank syariah.

Sementara Bapak Hilal mengatakan produk-produk bank syariah belum familiar ditelinganya karena menurut dirinya bahwa promosi bank syariah masih minim terlihat. Selain itu, dirinya merasa juga atm bank syariah sedikit terlihat, sehingga sangat mennyulitkan dirinya untuk menarik tunai walaupun ada ATM bersama namun itu merupakan bentuk pelayanan. Selama ini dirinya belum memikirkan untuk berpindah dari bank konvensional ke bank syariah karena memang dirinya sudah memiliki tabungan di bank konvensional serta ketidak pahaman dirinya terhadap bank syariah dan belum ada sesuatu yang menari yang membuat dirinya merubah fikirannya.

\section{PEMBAHASAN}

Bank syariah mulai berkembang pada era 90an dengan diawali oleh bank Muamalat pada saat itu telah memberikan warna baru bagi perbankan di Indonesia. Indonesia tergolong lambat mengingat terdapat beberapa negara lain yang telah mengadopsi bank syariah menjadi bagian dari perbankan di negaranya. Keterlambatan itu bukan lah menjadi penghalang dari tumbuh kembang perbankan syariah di Indonesia umumnya dan di Pekanbaru khususnya.

Salah satu yang mempengaruhi perkembangan dari bank syariah dengan melalui peningkatan strategi pelayanan ke nasabah ataupun calon nasabah. Strategi untuk melakukan pelayanan yang terbaik menjadi satu pilihan bilamana bank syariah ingin berkembang dan semakin tumbuh dari tahun ke tahun jumlah nasabahnya. Bank syariah yang merupakan lembaga bisnis, bukan lembaga kemanusiaan yang memaksa mau tidak mau harus memberikan yang terbaik untuk nasabah maupun masyarakat yang akan di jadikan nasabah dengan memberikan beberapa pengetahuan mauupun penawaran yang terbaik yang bisa diberikan. Pembentukan persepsi akan memberikan dampak terhadap kemajuan bank syariah juga akan mendorong masyarakat untuk dapat menggunakan jasa bank syariah sebagai lembaga keuangan. Persepsi dirasakan sangat penting, karena Persepsi adalah sebuah proses saat individu mengatur dan menginterpretasikan kesankesan sensoris mereka guna memberikan arti bagi lingkungan mereka.

Penelitian dilakukan dengan mewawancarai 5 informan yang berada di wilayah Pekanbaru. Dari hasil penelitian di lapangan, di peroleh data yang dapat memberikan banyak informasi yang berkaitan dengan potensi-potensi yang dapat dioptimalkan dari wilayah Pekanbaru umumnya dan kecamatan maupun kelurahan-kelurahan khususnya untuk dapat merubah persepsi masyarakat tentang perbankan syariah. Dari hasil observasi dan wawancara yang dilakukan kemudian 
peneliti melakukan analisis persepsi masyarakat yang tidak memilih bank syariah terhadap bank syariah serta faktor-faktor yang menyebabkan masyarakat tidak memilih bank syariah di wilayah Pekanbaru.

Dari hasil wawancara yang dilakukan ke informan memperoleh beberapa persepsi masyarakat Pekanbaru yang tidak memilih bank syariah di antaranya yaitu masyarakat Pekanbaru menganggap bahwa bank syariah dan bank konvensional sama secara aplikasinya sama, hanya istilah istilah yang digunakan saja yang berbeda. Masyarakat yang tidak memilih bank syariah menganggap demikian karena memang keterbatasan mereka akan pengetahuan serta minimnya edukasi yang mereka dapatkan dari praktisi perbankan maupun dari mediamedia promosi seperti televisi, media cetak serta media sosial.

Bank syariah dianggap seperti bankbank apada umumnya, hal ini tidak terlepas dari akibat kurangnya pemahaman dari masyarakat serta minimnya edukasi yang dilakukan pihak perbankan syariah mengenai konsep baru ini yang di aplikasikan di dunia perbankan. Kurangnya pemahaman serta minimnya edukasi yang mereka dapatkan memberikan persepsi yang berbeda mengenai produk bank syariah, hal ini tidak sesuai dengan realita sesungguhnya bahwa bank syariah merupakan bank yang mengadopsi nilai-nilai syariah Islam yang mengharamkan bunga.

Promosi yang dilakukan oleh bank syariah baik yang berada disekitar maupun yang tidak berada di sekitar lingkungan masyarakat dirasa kurang, promosi yang menekankan pada edukasi kemasyarakat dengan menjelaskan sebuah sistem baru yang dapat memberikan alternatif ataupun menjadi pilihan utama bagi para masyarakat secara luas. Edukasi sangat dibutuhkan hal ini dapat memberikan pemahaman kepada masyarakat mengenai bank syariah yang memang konsep baru di dunia perbankan apalagi di Indonesia yang baru berkembang kurang lebih sekitar tahun 90an. Edukasi ini berkaitan dengan perkenalan mengenai konsep bank syariah, istilah-istilah, serta produk-produk jasa yang memang dirasa masyarakat sebuah pengetahuan yang baru yang selama ini belum mereka mengerti.

Masyarakat menginginkan bahwa bank syariah dapat melakukan surveysurvey yang dibarengi masyarakat serta pemberian pemahaman mengenai bank syariah. Survey ini bisa saja digunakan untuk melihat permasalahan dari bawah, terkait perkembangan bank syariah. Selain itu juga masyarakat menginginkan diadakannya seminar-seminar kemasyarakatan yang juga bertemakan bank syariah yang dapat memberikan pemahaman mereka lebih baik, banyak dari mereka memberikan ketertarikannya setelah diberikan pemehaman sedikit mengenai bank syariah, maksut dan tujuannya bahwa masyarakat ingin mengetahui dan memahami bank syariah terlepas dari menabung atau tidaknya mereka pada bank syariah setidaknya terdapat keinginan untuk mengetahui konsep bank syariah. Artinya bahwa sesungguhnya kendala mereka hanya pada pemahaman serta ketidak tahuan terhadap konsep baru dan sistem baru yaitu sistem perbankan syariah dengan bank syariah yang menjalankannya. Edukasi ini memang tidak memberikan jaminan bahwa bank syariah akan banyak yang menggunakannnya namun setidaknya dapat memberikan pemahaman yang dapat setidaknya mendorong seseorang untuk menabung di bank syariah dan berpersepsi tentang bank syariah yang sesuai dengan realita yang terjadi.

Dari responden yang beranggapan bahwa bank syariah sama dengan bank konvensional, mereka juga beranggapan bahwa bank syariah selama ini hanya untuk mereka-mereka yang mengetahui tidak untuk masyarakat secara luas bank syariah. Artinya bahwa target promosi bank syariah selama ini tidak untuk seluruh umat melainkan hanya untuk mereka yang memahami Islam serta sistem perbankan syariah dan tidak memberikan pemahaman kepada mereka-mereka yang belum memahami sistem perbankan syariah. Mereka beranggapan bahwa bank syariah 
sama dengan bank konvensional, anggapan bahwa bank syariah untuk mereka yang mengetahui dan memahami Islam maupun secara umum terhadap bank syariah. Lagilagi persepsi ini muncul karena kurangnya edukasi kepada mereka yang tidak mengetahui, atau bisa dibilang mereka para praktisi bank syariah hanya menerapkan strategi pemasaran dan memposisikan dirinya disebelah orang-orang yang memang dari awal paham akan sistem ini tanpa melakukan ke pada masyarakat secara luas yang tidak paham akan sistem perbankan syariah ini.

Sosialisasi dan memberikan edukasi ke masyarakat secara luas menjadi sebuah kebutuhan yang sangat mendesak melihat pemahaman masyarakat tentang bank syariah sangat rendah. Edukasi dapat diberikan kepada masyarakat dengan banyak cara diantaranya dpat juga dilakukan melalui promosi secara langsung maupun promosi melalui media-media. Promosi secara langsung kepada masyarakat menjadi sebuah solusi yang real yang bisa dilakukan bank syariah secara luas. Promosi secara langsung juga dapat melihat problematika permasalahan tentang ketidak pahaman masyarakat mengenai bank syariah. promosi secara ini menurut masyarakat yang menjadi responden menginginkan pendekatan kemasyarakatan dengan mengadakan seminar-seminar perbankan memperkenalkan konsep perbankan syariah baik secara teoritis maupun aplikasinya, namun materi juga dikemas sebaik mungkin sehingga mudah untuk dipahami masyarakat secara luas.

Promosi-promosi melalui media pun juga tidak bisa di tinggalkan namun harus lebih diperhatikan muatan-muatan yang mengedukasi konsumen. Media sudah menjadi satu hal yang tidak bisa dihilangkan dari kehidupan masyarakat baik media elektronik, media cetak bahkan media sosial yang akhir-akhir ini memberikan banyak manfaat, baik bagi masyarakat maupun bagi perusahan. Seharusnya ini dapat dimanfaatkan semaksimal mungkin untuk promosi sekaligus mengedukasi masyarakat mengenai perbankan syariah yang memang masih baru bahkan asing bagi telinga mereka baik istilah maupun konsepnya.

Selain itu ada informan menyatakan bahwa bank syariah merupakan bank yang secara konsep mengadopsi konsep Islam dengan hukum syariah yang mengharamkan riba serta ketidakpastian atau spekulasi serta menggantikannya dengan proporsi bagi hasil dan menjunjung kepastian. Bank syariah mampu menjadi alternatif bahkan menjadi pilihan konsep perbankan dan mampu menggantikan yang selama ini dipakai. Bank syariah merupakan bank yang menjalankan prinsip-prinsip syariah dalam aplikasinya. Beberapa orang dari mereka sebelumnya memang sudah mengetahui bank syariah, baik mengetahui dari keluarga dekat maupu dari iklan-iklan bank syariah serta mengetahui karena terdapat kata Islam maupun syariah pada kata bank syariah.

Pengetahuan mereka terhadap bunga bank pun beragam, ada yang mengatakan bahwa bunga bank itu haram dan ada yang mengahalalkan bunga bank. Adapun yang menyatakan bahwa bunga bank itu haram karena mereka memang mengetahui bahwa bunga bank kovensional sama kaitannya dengan riba. Sedangkan yang menyatakan menghalalkan bunga bank karena memang faktor kebiasaan mereka terhadap bank konvensional yang memang mengadopsi bunga pada aplikasi perbankannya.

Nada negatif masih sering terdengar sebagian besar masyarakat terhadap perbankan syariah dan lembaga keuangan syariah lainnya bahwa perbedaan bank syariah dengan bank konvensional hanya pada kosa kata belaka dan penggantian bunga diganti dengan sistem bagi hasil. Umumnya orang hanya tahu bahwa bank syariah adalah bank tanpa bunga dan tidak tahu sama sekali mengenai mekanisme bagi hasil sehingga sering bertanya-tanya kalau menabung di bank syariah dan tidak mendapatkan bunga lalu apa yang mereka dapatkan. Disisi lain menurut persepsi mereka yang namanya bagi hasil pasti nilainya lebih kecil dari bunga bank. Persepsi ini muncul juga karena mereka mengira-ngira dan membandingkan dengan 
bunga yang selama ini menjadi bagian dari dunia perbankan mereka. Seharusnya pemberian pengetahuan serta bukti secara kongkrit yang terjadi di perbankan mengenai bagi hasil dapat memberikan alternatif meembuat persepsi yang salah mereka terhadap bagi hasil di bank syariah.

Tidak dipungkiri memang bahwa bank syariah merupakan lembaga bisnis, mau atau tidak harus memberikan nilai lebih terhadap produknya yang salah satunya berupa nilai balik yang konsumen atau nasabah dapatkan setelah menabung atau meminjam uang di bank syariah. Sementara bank syariah dengan sistim bagi hasil tidak memberikan kepastian pendapatan sebagaimana bunga bank konvensional memberikan kepastian pendapatan. Sedang menurut sebagian wirausaha yang membutuhkan pinjaman, menyatakan kredit di bank syariah prosesnya rumit dan berbelitbelit. Bank syariah dirasa lebih rumit ketimbang bank konvensional, dari akad maupun tata cara peminjamannya.

Pengetahuan masyarakat terhadap perbankan syariah sangat minim, mungkin hal ini terjadi karena promosi yang dilakukan perbankan kurang efektif dan tidak bisa langsung menjamah masyarakat secara luas, bisa dibilang bahwa segmentasi perbankan syariah merupakan mereka-mereka yang secara konsep mengerti dan mereka-mereka yang melihat bahwa terdapat faktor agama dalam perbankan syariah. namun realitanya yang menabung karena agama lebih kecil daripada mereka yang tidak menabung. Sesungguhnya potensi nasabah bank syariah sangat luas apabila masyarakat terjamah dari edukasi lewat promosi serta pemahamannya. Masyarakat Pekanbaru memiliki motivasi yang tinggi mengenai perbankan syariah, terlebih ketika diberikan penjelasan mengenai bank syariah secara konsep maupun aplikasinya. Mereka merespon secara positif hadirnya perbankan syariah yang menanamkan prinsip syariah dalam aplikasinya.

Bank syariah yang merupakan lembaga keuangan yang menerapkan prinsipprinsip syariah yang mengharamkan bunga.
Saat-saat ini perkembagan bank syariah semakin maju melihat dari tahun ketahun dana pihak ketiga yang tersimpan di bank syariah semakin bertambah, walaupun belum dapat menyaingi bank konvensional. Hal itu terjadi karena keberadaan bank syariah masih seumur jagung dibandingkan dengan bank konvensional yang sudah ada di Indonesia sejak lama. Bank syariah yang mengadopsi nilai-nilai Islam dalam aplikasinya, hal ini yang seharusnya menjadi nilai plus perkembangan bank syariah di Indonesia umumnya dan khusunya di Surabaya khususnya yang mayoritas muslim.

Agama menjadi salah satu motivasi masyarakat untuk menabung di bank syariah, namun dengan mayoritas penduduk muslim seharusnya bank syariah mampu untuk bersaing dengan bank konvensional yang menggunakan variabel bunga yang diharamkan dalam Islam. Masyarakat masih belum dapat beralih dari bank konvensional ke bank syariah, hal itu dipengaruhi oleh beberapa faktor diantaranya yaitu faktor bauran pemasaran. bauran pemsaran menjadi sebuah strategi pemasaran yang seharusnya ada dan diterapkan secara efektif dalam perkembangan perbankan syariah. Bauran pemasaran merupakan salah satu strategi pemasaran yang memang dapat mendorong masyarakat memilih bank syariah.

Setelah melakukan wawancara dengan 5 informan di Pekanbaru, mendapatkan beberapa jawaban mengenai faktor yang menyebabkan masyarakat Pekanbaru tidak memilih bank syariah. Faktor-faktor yang menyebabkan masyarakat tidak memilih bank syariah ini muncul berdasarkan wawancara secara mengalir guna untuk mengungkap beberapa alasan masyarakat dan argumen mereka untuk tidak memilih bank syariah sebagai pilihan utama atau alternatif lembaga keuangan yang ada.

Faktor yang menyebabkan masyarakat tidak memilih bank syariah antara lain karena kurangnya pengetahuan masyarakat Pekanbaru terhadap bank 
syariah. Produk bank syariah mereka anggap belum merakyat dan tidak banyak diketahui masyarakat secara luas. Hal ini karena mereka anggap promosi yang dilakukan bank syariah terhadap produk-produknya belum banyak dan belum menjangkau mereka sebagai masyarakat.

Pengetahuan masyarakat Pekanbaru tehadap produk bank syariah sangat rendah. Pengetahuan masyarakat Pekanbaru terhadap produk-produk bank syariah yang rendah, menjadikan bank syariah tidak dipilih oleh masyarakat sebagai pilihan utama atau pun alternatif sebagai lembaga keuangan yang menyimpan dana mereka. Masyarakat Pekanbaru merasa selama ini tidak dijangkau oleh promosi-promosi bank syariah. Eventevent bank syariah yang menyentuh secara langsung bank syariah dirasa tidak ada. Bank syariah selama ini belum banyak melakukan event-event yang menyentuh masyarakat Pekanbaru secara langsung baik di pasarpasar didaerah Pekanbaru maupun di tempat keramaian lainnya.

Selain event-event, penawaran promo yang dilakukan bank syariah juga menjadi faktor yang meyebabkan mereka untuk tidak memilih bank syariah, promo merupakan salah satu yang mendorong nasabah untuk memilih bank syariah. Promo-promo yang menarik seperti yang dilakukan bank konvensional selama ini tidak mereka dapatkan seperti yang mereka dapatkan di bank syariah. Promo-promo ini merupakan bagian dari penawan produk ke masyarakat terkait dengan produk baru ataupun pemberian reward terhadap nasabah yang loyal terhadap bank syariah.

Produk bank syariah seperti tabungan wadi'ah dan mudharabah dirasa masyarakat sulit untuk dipahami. Istilah maupun konsep pembagian hasil masyarakat anggap sebuah pengetahuan yang baru, yang selama ini masih sedikit bahkan hal baru bagi mereka. Produk bank syariah mereka anggap sebuah hal yang baru karena selama ini mereka mendapatkan informasi yang sengat terbatas. Hal ini terjadi karena terbatasnya informasi yang mereka dapatkan baik melalui media maupun informasi secara langsung dari marketing bank syariah.

Prinsip untuk mengharamkan bunga pada bank syariah membuat anggapan yang berbeda masyarakat terhadap bank syariah. Mereka beranggapan tidak akan mendapatkan apa-apa ketika menyimpan uangnya di bank syariah. Adapula yang beranggapan bahwa bagi hasil pada bank syariah tidak menentu sehingga tidak memberikan kepastian jumlahnya perbulan sehingga mereka beranggapan bahwa penerapan bagi hasil pada bank syariah tidak menguntungkan bagi nasabah. Anggapan ini muncul merupakan hal yang wajar mengingat minimnya informasi yang mereka dapatkan. Bank konvensional yang selama ini berada di lingkungan mereka telah banyak mempengaruhi kehidupan mereka, sehingga akan membutuhkan waktu lama merubah pandangan mereka jika bank syariah tidak bersunggu-sungguh untuk menerapkan prinsip syariah di Indonesia umumnya dan Pekanbaru khususnya.

Selain itu, mereka juga menganggap bahwa produk-produk bank syariah dirasa kurang menarik. Mereka menganggap bahwa bank syariah merupakan bank baru yang belum meiliki nama di dunia perbankan. Image produk bank syariah belum dikenal masyarakat, sehingga rasa gengsi untuk memilih bank syariah sebagai lembaga keuangan yang mereka pilih sangat tinggi. Rasa gengsi ini muncul karena brand bank syariah dirasa belum banyak terkenal dan belum banyak diminati nasabah khusunya kaum muda yang lebih mementingkan brand dari pada kualitasnya.

Promosi bank syariah melalui media electronik, media cetak dan media sosial dirasa belum maksimal. Padahal promosi merupakan media untuk memperkenalkan produk baik dari segi fisik maupun brand, promosi menjadi sangat penting karena pada proses inilah barang di perkenalkan masyarakat secara luas. Promosi juga menjadi rangkaian proses pemasaran setelah produk, harga serta saluran distribusi telah ditetapkan. Promosi menjadi salah satu strategi dalam bauran pemasaran 
yang berfungsi untuk menjelaskan produk secara menyeluruh kepada masyarakat secara luas.

Bank konvensional selama ini lebih memberikan promosi-promosi yang cukup menarik bagi mereka seorang pengusaha dengan langsung mendatangi mereka, baik untuk menawarkan produk baru di lembaga perbankannya ataupun juga menawarkan untuk menjadi nasabah baru. Hal ini terlihat bahwa promosi bank syariah untuk memperkenalkan ke masyarakat secara umum masih kalah bersaingg dengan bank konvensional, padahal ini bagian dari pelayanan sekaligus bisa dimanfaatkan untuk mengedukasi mengenai perbankan syariah baik secra produknya maupun konsepnya.

Strategi jemput bola menjadi alternatif promosi bank syariah. sengan langsung terjun dan mendekatkan diri ke masyarakat sehingga mereka dapat mengerti problematika masalah yang terjadi sehingga masyarakat Pekanbaru yang mayoritas muslim tidak memilih bank syariah. Strategi jemput bola juga bagian dari strategi mendekatkan diri dengan masyarakat sekaligus mengedukasi masyarakat yang tidak memahami bank syariah. Strategi jemput bola juga dapat berbentuk seminarseminar tentang bank syariah sekaligus menawarkan produk dan mengedukasi kemasyarakat. Masyarakat sesungguhnya mudah untuk diajak komunikasi apabila semuanya jelas.

Ketidaktahuan masyarakat terhadap bank syariah juga dipengaruhi oleh beberapa faktor diantaranya informan tidak lagi mencari informasi tentang bank syariah karena memang mereka menganggap bahwa bank syariah sama dengan bank konvensional yang selama ini mereka gunakan. Mereka menganggap bahwa menabung dimana saja sama, yang akhirnya membuat mereka nyaman dengan keadaan mereka saat ini sehingga mereka menentukan pilihan untuk tidak menabung di bank syariah. Selain itu menurutnya belum adanya sesuatu yang mendorong mereka untuk mempelajari ataupun sekedar mengetahui bank syariah. sesuatu yang mendorong ini berupa promo yang menarik dari bank syariah.

Adapula faktor yang membuat masyarakat tidak memilih bank syariah mengenai tempat. Faktor tempat ini maksutnya adalah keberadaan kantor cabang maupun cabang pembantu yang jauh dari tempat tinggal masyarakat. Masyarakat merasa bahwa keberadaan kantor ini merupakan sebuah wujud dari pelayanan bank syariah terhadap nasabah. Keberadaan kantor bank syariah yang dekat dengan masyarakat membuat mereka lebih mudah untuk mengakses informasi mengenai bank syariah. Sementara ini bank konvensional dianggap lebih dekat dengan lingkungan mereka, sehingga informasi yang mereka dapatkan juga mengenai promo-promo serta event yang dilakukan oleh bank konvensional dan membuat mereka mau tidak mau juga menabung di bank konvensional.

Keberadaan kantor pelayanan bank syariah yang berada dekat dengan masyarakat dirasa memudahkan mereka untuk melakukan aktifitas perbankannya. Karena memang hampir sebagan besar penduduk surabaya yang bekerja sebagai karyawan, sehingga waktu untuk beraktifitas yang terbatas. Akhirnya mereka menjatuhkan pilihan ke bank yang memang lebih dekat dengan mereka dan menjatuhkan pilihan ke bank konvensional. Keberadaan kantor pelayanan yang dekat dengan masyarakat juga menunjukan eksistensi dan keberadaan mereka sebagai lembaga bisnis yang ingin mendekatkan diri dengan masyarakat. Mungkin tidak semudah itu mengatakan bank syariah tidak dekat dengan masyarakat namun tafsiran yang terjadi di masyarakat seperti itu, hal ini bisa menjadi pertimbanganserta informasi bagi pelaku bisnis perbankan serta bagian marketing untuk dapat menepatkan diri dengan masyarakat.

Keberadaan kantor bank syariah yang dekat dengan bank syariah memang bukan satu-satunya wujud pelayanan bank syariah tetapi sangat penting karena ditempat inilah pusat informasi bank syariah bisa diakses oleh masyarakat. 
Adapun yang beranggapan bahwa tempat memang sesuatu yang penting namun bukan segalanya ketika masyarakat memahami tentang bank syariah dan mengerti produk yang dijual bank syariah maka dimana pun bank syariah berada akan di cari oleh nasabah. Anggapan ini merupakan anggapan yang relevan jika memang kebutuhan masyarakat terpenuhi karena adanya bank syariah.

Keberadaan ATM yang terbatas juga menjadikan masyarakat Pekanbaru tidak memilih bank syariah. ATM merupakan bagian dari pelayanan bank yakni untuk mempermudah nasabah mengambil uangnya yang di simpan di bank. Masyarakat menginginkan bahwa banyak nya ATM di tempat-tempat umum yang biasa mereka datangi merupakan bagian dari alasan mereka untuk menabung di bank. Meskipun adanya ATM bersama, mereka menganggap mengambil uang di ATM bersama ataupun di bank konvensional yang satu nama dengan bank syariah akan mengakibatkan pemotongan administrasi.

Beberapa faktor yang menyebabkan masyarakat tidak memilih bank syariah ini menjadi banyak permasalahan yaitu pada pengetahuan masyarakat terhadap bank syariah yang minim. Promosi bank syariah yang dilakukan sangat sedikit dan sangat minim pengaruhnya terhadap pengetahuan masyarakat terhadap bank syariah. Pengetahuan nasabah terhadap bank syariah ini akan menjadikan persepsi mereka yang salah mengenai bank syariah akan berubah dan sesuai dengan realitanya. Perubahan pengetahuan ini akan banyak mendorong mereka untuk menabung di bank syariah. Mereka sebenarnya sudah banyak yang memahami bahwa bank syariah itu haram namun sedikit pemahamn mereka mengenai konsep bagi hasil pada bank syariah.

Promosi yang menekankan edukasi menjadi kebutuhan bank syariah jika ingin mengembangkan bisnis bank syariah nya dan memperkenalkan konsep syariah di masyarakat secara luas. Promosi dengan melakukan pendekatan masyarakat serta melihat problematika yang terjadi secara langsung dimasyarakat mengenai penyebab masyarakat yang mayoritas muslim ini tidak memilih bank syariah sebagai lembaga keuangan harus menjadai pilihan utama. Loyalitas nasabah terhadap bank konvensional yang selama ini menjadi satusatunya pilihan untuk menabung di bank syariah menjadi satu tantangan bank syariah.

Melihat beberapa anggapan mengenai tempat atau lokasi kantor cabang maupun cabang pembantu, yang terjadi pada informan yang menyatakan bahwa tempat bukan lah sesuatu yang penting jika pemahaman akan produk yang mereka beli atau yang mereka gunakan secara penuh mereka ketahui. Tempat sesungguhnya juga bagian penting dalam sebuah perusahaan jasa, karena itu merupakan pelayanan. Namun tempat itu bersifat relatif dan satu sama lain orang akan melihat jauh dan dekatnya tempat itu berbeda. Hal ini karena kebutuhan mereka akan lembaga perbankan syariah yang sesuai dengan ideologi serta nilai-nilai keislamanya. 


\section{SIMPULAN}

Dari hasil penelitian dilapangan terdapat beberapa persepsi masyarakat mengenai bank syariah di antaranya adalah: Pengetahuan masyarakat terhadap bank syariah sangat rendah, mengingat mereka sangat minim mendapatkan informasi dari pelaku bisnis bank syariah maupun marketing bank syariah. Masyarakat Pekanbaru berpersepsi bahwa bank syariah sama dengan bank konvensional. Adapun yang mempengaruhi masyarakat berpersepsi seperti ini, karena mereka mendapatkan informasi yang sedikit, baik dari media electronik, media cetak, maupun media sosial. Selain itu juga terdapat anggapan bahwa bank syariah ada untuk mereka yang memahami Islam, tidak untuk mereka yang belum memahami prinsip ini. Hal ini karena mereka menganggap belum tersentuhnya oleh edukasi yang dilakukan bank syariah. Persepsi masyarakat mengenai bunga bank konvensional sebagian besar dari mereka menganggap haram. Bunga bank haram karena memang masyarakat lebih mengetahui persamaanya dengan riba yang sesungguhnya dilarang oleh agama.

Faktor yang menyebabkan masyarakat tidak memilih bank syariah jika melihat dari aspek bauran pemasarana sangat relatif jawabannya yang diantaranya adalah: Pengetahuan masyarakat akan produk bank syariah, Daya tarik produk bank syariah mereka rasa kurang, Sistem bank syariah di rasa kurang merakyat, Persepsi masyarakat akan produk bank syariah sama dengan bank konvensional, Promosi yang dilakukan bank syariah kurang mengedukasi masyarakat, sehingga berpengaruh terhadap pengetahuan masyarakat dan akhirnya kurang mendorong masyarakat untuk menggunakan bank syariah sebagai pilihan utama sebagai lembaga keuangan, Penerapan bagi hasil yang dianggap kurang menarik, karena tidak memberikan kepastian pendapatan dan kecil dibandingkan bunga pada bank konvensional, Event ataupun promosi yang kurang, Branding bank syariah juga masih rendah, yang akhirnya menimbulkan gengsi tersendiri untuk menggunakannya sebagai lembaga keuangan, Bagi hasil yang diterapkan di bank syariah dianggap sedikit dari pada bunga, Keberadaan tempat kantor cabang maupun cabang pembantu yang tidak dekat dengan masyarakat dan Terbatasnya ATM.

\section{DAFTAR RUJUKAN}

Chair Wasilul, Riba Dalam Perspektif Islam dan Sejarah, Iqtishadia: Jurnal Ekonomi Dan Perbankan Syariah, E-ISSN: 2442-3076, Vol 1, No. 1, 2014.

Imam, Sentot, Manajemen Perbankan Bank. Yogyakarta, Graha Ilmu, 2010

Kasmir, Bank dan Lembaga Keungan Lainnya, Cetakan Kesebelas, Jakarta: Raja Grafindo Persada, 2012

Kolistiawan Budi, Tinjauan Syariah Tentang Pembiayaan Bermasalah Di Perbankan Syariah, An-Nisbah: Jurnal Ekonomi Syariah, E-ISSN: 2549-5712, Vol. 1, No. 1, 2014

Nofinawati, Perkembangan Perbankan Syariah Di Indonesia, Juris: Jurnal Ilmu Syariah, E-ISSN: 2580-2763, Vol. 14, No. 2, 2015.

Rahmawaty, Anita, Ekonomi Syariah: Tinjauan Kritis Produk Murahabah Dalam Perbankan Syariah di Indonesia, La_Riba: Jurnal Ekonomi Islam, Vol. 1, No. 2, Desember 2007.

Ramadhani Mutia dan Isfandayani, Analisis Perbandingan Tingkat Kesehatan Bank Syariah Devisa dan Non Devisa Dengan Menggunakan Metode Camel, Maslahah: Jurnal Hukum Islam Dan Perbankan Syariah, E-ISSN: 2086-5678, Vol. 5, No. 1, Mei 2014. 
Sofyan Syaakir, Perkembangan Perbankan Syariah Di Indonesia, Bilancia: Jurnal Studi Ilmu Syariah Dan Hukum, E-ISSN: 1978-5747, Vol. 10, NO. 2, Juli-Desember 2016.

Susila Jaka, Fiduciary Dalam Produk-Produk Perbankan Syariah, Al-Ahkam: Jurnal Ilmu Syariah Dan Hukum, EISSN: 2527-8150, Vol. 1, No. 2, 2016

Syamsu, Moh. Rizaldi, Aspek Hukum Rahasia Bank Di Indonesia, Lex Privatum: Jurnal Elektronik Bagian Hukum Dan Keperdataan Fakultas Hukum Unsrat, Vol. 1, NO. 1, Januari-Maret 2013

Triwahyuningtyas, Endah, Analisis Kinerja Keuangan Bank Umum Syariah Dan Faktor-Faktor Yang Mempengaruhinya, E-Jurnal Manajemen Kerja, E-ISSN: 24077305, Vol. 1, No. 2, Juli 2015.

Yatie, Vivieta Ary, Analisis Faktor-Faktor Yang Mempengaruhi Nasabah Menabung, Jurnal Pendidikan Akuntansi (JPAK), E-ISSN: 23376457, Vol. 5, No. 3, 2017

Wibowo Edy, S.H, M.H dan Widodo Hendy Untung, S.H., Mengapa Memilih Bank Syariah?, Penerbit Ghalia Indonesia. Bogor Selatan, 2005 